\title{
İnşaat Sektörünün Dinamikleri: Türkiye için 2000-2014 Girdi-Çıkt1 Analizi
}

The Dynamics of the Construction Sector: An Input-Output Analysis of Turkey for the 2000-2014 Period

\author{
Zafer Barış GÜL ${ }^{1}$ \\ Misra ÇAKALOĞLU²
}

Geliş tarihi: 04.04.2017, Kabul tarihi: 25.07.2017, Basım tarihi: 20.11.2017

\section{Özet}

Türkiye'de inşaat sektörü, gerek altyapı yatırımları, gerekse konut inşaatları çerçevesinden bakıldığında, son yıllarda öne çıkan sektörler arasında yer almaktadır. Genel olarak inşaat sektörü, güçlü sektörel bağlantıları nedeniyle ekonominin sürükleyici sektörlerinden biri olarak kabul edilmektedir. Ülkemizde 2000 sonras1 dönem ele alındığında, sektörün büyüme hızı hemen her dönemde GSYİH büyüme hızının üzerinde bir seyir izlemiştir. Bu çalışmada, World Input-Output Database (WIOD) projesinden alınan güncellenmiş 2000-2014 yılları arası girdi-çıtıtı tabloları kullanılmıştır. Bu girdi-çıktı tablolarından ileri ve geri bağlantılar ile çıtı, gelir, istihdam gibi çeşitli çarpanlar hesaplanmıştır. Çalışmada girdi-çıktı analizi sonucu hesaplanan yapısal parametreler ışığında, inşaat sektörünün ekonominin lokomotif sektörü olarak görülebilme ihtimalini tartışmak amaçlanmaktadır.

Anahtar Kelimeler: Inşaat Sektörü, Girdi-Cıktı Analiž, Geri ve İleri Bağlantılar, Carpanlar, Türkiye

JEL Kodlar1: L74, D57, R30

\begin{abstract}
The construction sector in Turkey has been a prominent sector recently with respect to the infrastructure investments and housing constructions. It is widely accepted that the construction industry is considered to be one of the main drivers of the overall economy due to its strong inter-industrial linkages. The growth rate of construction sector in Turkey has shown a trend above the average GDP growth rate almost in each period after the 2000 era. In this study, the updated input-output tables constructed by the World Input-Output Database (WIOD) project from 2000-2014 are employed and backward-forward linkages and several multipliers are also calculated by using these input-output tables. In this study, it is aimed to discuss whether the construction industry can be considered as the driver of the economy.
\end{abstract}

\footnotetext{
1 Akdeniz Üniversitesi İktisadi ve İdari Bilimler Fakültesi, İktisat Bölümü, Yrd. Doç. Dr. zafergul@akdeniz.edu.tr

2 Antalya AKEV Üniversitesi Meslek Yüksek Okulu, Öğretim Görevlisi

msr_ck103@hotmail.com
} 
Keywords: Construction Sector, input-output analysis, backward-forward linkages, multipliers, Turkey

Jel Codes: L74, D57, R30

\section{Giriş}

İnşaat sektörü, özellikle gelişmekte olan ülkelerde altyapı ve konut yatırımları çerçevesinde düşünüldügünde, iktisadi gelişmeye katk1 yapan sektörlerin başında gelmektedir. İnşaat sektörü ve sektörün iktisadi gelişme ile olan ilişkisi, ilk olarak 1960’ların sonu ve 1970’lerin başlarında Turin (1969) ve Strassmann (1970)'in çalışmaları ile ortaya konmuştur. Turin ve Strassmann, inşaat sektörünün kişi başına düşen katma değeri ile kişi başına düşen gayrisafi yurtiçi hasıla arasında güçlü bir ilişsi olduğunu, kişi başına gayrisafi yurtiçi hasıla arttıkça, inşaat sektörünün kişi başına düşen katma değerinin de artış gösterdiğini ortaya koymuşlardır (Lewis, 2009: 37; Giang and Pheng, 2011: 119). Bunun yanı sıra, Strassmann (1970), inşaat sektörünün iktisadi büyümedeki sürükleyici rolüne dikkat çekmiş, özellikle ülkelerin iktisadi gelişmelerinin ilk aşamalarında, inşaat sektörünün ekonominin itici gücü olma konusunda imalat sektörünün önüne geçtiğini gözlemlemiştir.

İnşaat sektöründeki büyüme ile iktisadi gelişme evreleri arasındaki ilişki, Ranko Bon tarafından geliştirilen Bon eğrisi ile açıklanmaktadır. Bon (1992), ekonomilerin iktisadi gelişmelerinin farklı aşamalarında inşaat sektörünün rolünü araştırmış ve bir ülkenin iktisadi gelişme aşamalarına göre, inşaat sektörünün gelişim desenini çıkarmıştır. Buna göre, iktisadi gelişmenin erken aşamalarında, inşaat sektörünün ekonomideki payı artmakta, fakat ekonomi belirli bir gelişme düzeyine ulaştığında bu pay azalmaktadır. Tan (2002) bu durumu ters $U$ eğrisi olarak tanımlamakta ve şu şekilde açıklamaktadır. "...düssïk gelirli ülkelerde insaat sektörünün çıktısı düşüktür. Sanayilesme arttıksa, fabrika, ofis, altyapı ve konut ibtiyac bas gösterir. Bunun sonucu olarak, gayrisafi yurtici hasilann bir oran olarak insaat sektörünün ğktusl, orta gelirli ülkelerde en yülksek seviyeye ulasmaktadrr. Yüksesek gelirli ülkelerde insaat sektörünün gayrisafi yurtici hasila icerisindeki payl, altyapinn daba gelismis hale gelmesi ve konut ibtiyacmmn azalmasindan dolayn, giderek azalmaktadrr. ..." ekonominin gelişmişlik düzeyi arttıkça inşaat sektörünün milli gelir içindeki öneminin azalması olarak özetlenebilecek bu olgu, güncel çalışmalarla da doğrulanmaktadır (Lewis, 2009: 39).

Bu konuyla ilgili bir başka önemli nokta da inşaat sektörünün toplam yatırımlar içindeki payıdır. Genel olarak Lewis (2009) inşaat sektörünün, geçmişten bu yana, bir ülkenin gayrisafi sabit sermaye oluşumunda yaklaşık yüzde 50 'lik paya sahip olduğunu bulgulamıştır. Günümüzde ise gayrisafi sabit sermaye oluşumunda inşaat yatırımlarının payları gelişmiş ve gelişmekte olan ülkeler için sırasıyla yüzde 26 ve yüzde 23 'tür. 
$\mathrm{Bu}$ çalışmada amaç, inşaat sektörünün yapısını Girdi-Çıktı (GÇ) modellemesi çerçevesinde araştırmak ve 2000 sonrası dönem için sektörler arası bağlantılara dayanarak inşaat sektörünün diğer sektörler arasındaki konumunu ve sektörün zaman içindeki gelişim trendini ileri ve geri bağlantılar ile çarpanlar üzerinden ortaya koymaktır. Bu amaçla, World Input-Output Database (WIOD) projesinden alınan ve Ulusal Hesaplar Sistemi (SNA-2008) ile Avrupa Hesaplar Sistemi (ESA-2010) öncülügünde Avrupa Birliği ülkelerinde yapılan kapsamlı milli gelir revizyonları doğrultusunda güncellenmiş 2000-2014 yılları arası girdi-çıktı tabloları kullanılmıştır. 15 yıllık GÇ tabloları kullanılarak yapılan analizde başta geriye ve ileriye doğru bağlantılar olmak üzere, çıktı, girdi, kesikli (truncated) çıtı, kesikli gelir, kesikli tip II gelir, kesikli istihdam ve kesikli tip II istihdam çarpanları hesaplanmıştır. Bu hesaplamalarla Türkiye'de inşaat sektörünün 2000-2014 arasında ekonominin sürükleyici sektörlerinden biri olup olmadığının ortaya konulması amaçlanmaktadır.

Çalışmanın planı şu şekildedir. İlk olarak Türkiye'de 2000'den 2014'e 15 yıllık dönem boyunca inşaat sektörünün yapısı ve gelişimi, temel makroekonomik ve sektöre ilişkin göstergeler ışığında ele alınmakta, ardından inşaat sektörü ve sektörün ekonomi ile olan ilişkisi üzerine güncel literatür, GÇ analizi ana ekseni üzerinden özetlenmektedir. Veri ve yöntem kısmında hesaplamalara konu olan veri seti ile geriye ve ileriye doğru bağlantilar ile çarpanların nasıl hesaplandı̆̆ı anlatılmaktadır. Son olarak, hesaplamalardan elde edilen ampirik bulgular analiz edilmekte ve inşaat sektörünün ekonomi içerisindeki yerine ilişkin sonuçlar tartışılmaktadır.

\section{Türkiye'de İnşaat Sektörü: 2000-2014}

Türkiye ekonomisinde inşaat sektörü özellikle son 15 yıllık dönemde ciddi bir ivme kazansa da sektörün gelişim sürecini 1980 sonrası döneme kadar götürmek mümkündür. 1980’ler bu anlamda, özellikle 1982-1988 arasında inşaat sektörü açısından önemli bir büyüme dönemine tanıklık etmiştir. Gayrisafi yurtiçi hasıla içerisinde inşaat yatırımlarının payı 1982 yılında yüzde 5,2 iken 1987 'de bu oran yüzde 7,3'e çıkmıştır. Ayrıca inşaat sektörünün gayrisafi yurtiçi hasıla içindeki payı 1987 yllında, incelenen dönemin en yüksek noktasına ulaşmıştır (Balaban, 2011: 21-22).

Grafik 1, inşaat sektörünün katma değerindeki yıllık değişim ile, bir başka deyişle inşaat sektöründeki büyüme ile gayrisafi yurtiçi hasıla büyümesinin 2010 yılı sabit fiyatları ile 2000'den 2014 yllına kadar olan dönem boyunca gelişimini özetlemektedir. 


\section{Grafik 1. İnşaat sektörünün katma değer ve GSYİH büyüme oranı}

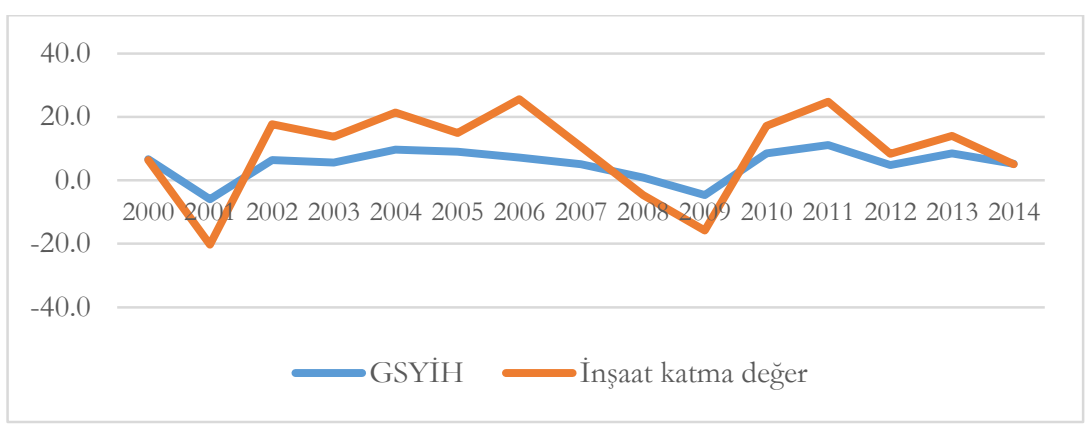

Kaynak: OECD

Ortalama büyüme oranları açısından bakıldığında, inşaat sektörünün 20002014 dönem ortalaması yüzde 9,2 iken gayrisafi yurtiçi hasılanın büyüme oranı yüzde 5,2'de kalmıştır. Grafikten de görüleceği üzere 2000-2001 dönemi ile küresel krizin yoğun hissedildiği 2008 ve 2009 ylları hariç, inşaat sektörü hemen her dönem gayrisafi yurtiçi hasılaya göre daha yüksek bir büyüme performansı sergilemiştir. İnşaat sektörünün büyümesi ile ulusal gelirin büyüme farkının, inşaat lehine, en fazla açıldığ1 yıllar önem büyüklüklerine göre sirasiyla, 18,4; 13,6; 11,7 ve 11,3 puan olmak üzere 2006, 2011, 2004 ve 2002 yıllarıdır. 2011, 2004 ve 2002 yıllarında inşaat sektörü, gayrisafi yurtiçi hasılaya göre neredeyse iki kattan; 2006 yılında ise üç kattan fazla büyümüştür.

Gayrisafi yurtiçi hasıladaki paylar dikkate alındığında, inşaat sektörünün 2000-2014 yilları arası ortalama pay1 \%6,4 ile 20 sektör $^{3}$ arasında altıncı sırada yer almaktadır. İnşaat sektörü gayrimenkul faaliyetleri ile birlikte ele alındığında \%15'lik dönem payı ortalaması ile imalat sektöründen sonra ikinci siraya yerleşmektedir.

İnşaat sektörü ile ekonomi arasındaki ilişkinin yönünü belirlemede, bir başka deyişle inşaat sektörü mü ekonomideki büyümeyi sağlamakta yoksa ekonomik büyüme mi inşaat sektöründeki büyümeyi tetiklemektedir sorusunun yanıtını vermede birikimli deneyim fonksiyonu (cumulative experience function) bize yol göstermektedir. Birikimli deneyim fonksiyonu

\footnotetext{
3 TÜÍK’in 2009 bazlı yeni milli gelir serisinde üretim yöntemiyle gayrisafi yurtiçi hasıla hesaplarında yer alan sektörler şunlardır: Tarım, ormancılık ve balıkçılık; madencilik ve taş ocakçllığı; imalat sanayi; elektrik, gaz, buhar ve havalandırma sistemi üretim ve dağıtımı; su temini, kanalizasyon, atık yönetimi ve iyileştirme faaliyetleri; inşaat; toptan ve perakende ticaret; ulaştırma, depolama; konaklama ve yiyecek hizmeti faaliyetleri; bilgi ve iletişim; finans ve sigorta faaliyetleri; gayrimenkul faaliyetleri; mesleki, bilimsel ve teknik faaliyetler; idari ve destek hizmet faaliyetleri; kamu yönetimi ve savunma, zorunlu sosyal güvenlik; eğitim; insan sağlı̆̆ ve sosyal hizmet faaliyetleri; kültür, sanat, eğlence, dinlence ve spor; diğer hizmet faaliyetleri; hanehalkının işveren olarak faaliyetleri.
} 
iki değişken arasındaki ilişkinin yönünü parametrik olmayan bir hesaplamaya dayanarak ölçer (Lewis, 2009: 53-54).

$$
\text { birikimli deneyim } x=\frac{\sum_{i=t_{0}}^{t} x_{t}}{\sum_{i=t_{0}}^{t_{1}} x_{t}}
$$

(1) numaralı denklem, birikimli deneyim fonksiyonunun formülünü vermektedir. Denklemde $t_{0}$ ve $t_{1}$ değisşkene ilişkin verinin başlangıç ve bitiş yillarını simgelemektedir. Değişkenlerin başlangıç döneminden bitiş dönemine kadar olan değerlerinin birikimli ortalamaları alınarak hesaplanan birikimli deneyim fonksiyonları, değişkenleri birbirleriyle karşılaştırmak suretiyle hangi değişkenin diğerini öncelediğini belirlemektedir. (2) numaralı grafik, inşaat sektörünün katma değeri ile gayrisafi yurt içi hasılanın birikimli deneyim fonksiyon değerlerini bir arada göstermektedir.

Grafik 2. İnşaat sektörü katma değeri ile gayrisafi yurtiçi hasılanın birikimli deneyim fonksiyon değerleri

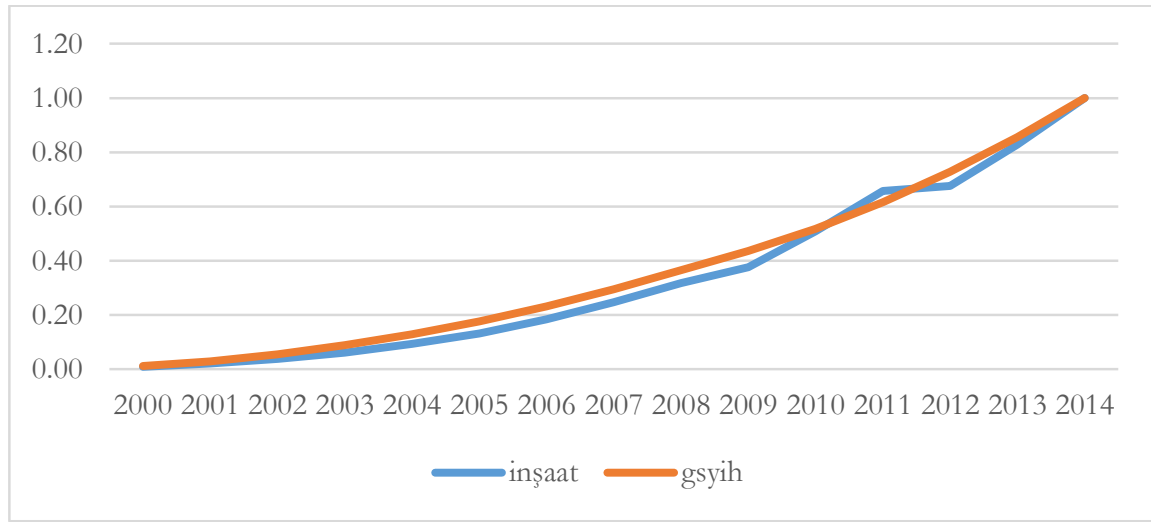

Kaynak: TÜiK

Değişkenlerin fonksiyon değerlerinin birbirleri ile göreli konumlarını resmeden grafik, hangi değişkenin konumu üstte ise o değişkenin, konumu altta kalan değişkenin gelişimine katkı yaptı̆̆ı, bir başka deyişle değişkeni sürüklediği şeklinde yorumlanmaktadır. Buna göre Türkiye'de 2000-2010 ile 2012-2014 y1lları arasında gayrisafi yurtiçi hasıla inşaat sektörünün gelişmesini desteklemiş, bir anlamda inşaat sektörünün büyümesinde itici güç olmuştur. Yalnızca 2011 yllında inşaat sektörünün ekonomiyi sürükleme etkisinin olduğu görülmektedir. Grafik 2'nin ortaya koyduğu sonuç, her ne kadar inşaat sektörü, 2000-2014 arasında ortalama olarak gayrisafi yurtiçi hasıladan daha hızlı büyüse de, bu büyümenin arkasında ekonominin inşaat sektörünü sürükleyici etkisinin olduğu şeklindedir. 


\section{Grafik 3. Gayrisafi sabit sermaye oluşumunun dağılımı}

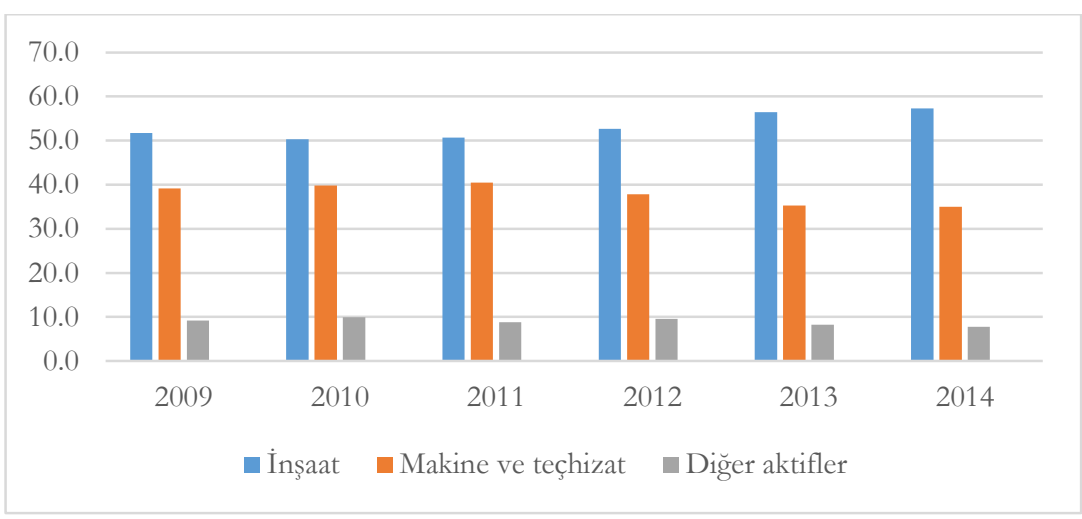

Kaynak: TÜİK

Grafik 3, 2009'dan 2014'e gayrisafi sabit sermaye oluşumunun dağılımını göstermektedir. Sermaye stokunda inşaatın payı 2009'da yüzde 51,7'den 2014'de yüzde 57,3'e çıkmış, buna karşın makine ve teçhizatın payı yüzde 39,1'den yüzde 34,9'a gerilemiştir. Artış ve azalışlar oransal olarak sırasıyla yüzde 10,8 ve 10,7 'ye tekabül etmektedir. İnşaatın sermaye stoku içindeki payında meydana gelen artış ile makine teçhizatın sermaye stoku içindeki payında meydana gelen azalış aynı oranlarda olmuştur. Makine ve teçhizat stokundaki bu erime, Türkiye'nin ihracata dönük katma değer yaratma kapasitesinde ciddi bir düşüş yaratması bağlamında düşündürücüdür.

\section{2. İnşaat Sektörü üzerine Yapılmış Çalı̧̧malar}

İnşaat sektörü ile ilgili olarak, sektörün ekonomi ile olan ilişkisini, bir taraftan yalnızca inşaat sektörü ve iktisadi büyüme çerçevesinde ele alan çalışmaların yanı sıra, sektörü iktisadi kalkınma bağlamında daha geniş bir perspektiften değerlendiren çalışmaların da olduğu geniş bir literatür bulunmaktadır (Giang ve Pheng, 2011: 119). Bu kisımda, öncelikle dünya genelinde ve ardından Türkiye için yapılmış makroekonomik ve sektörel göstergelere dayalı betimsel çalışmalar kısaca özetlenmekte ve inşaat sektörü ile ilgili GÇ analizi yapan çalışmalara yer verilmektedir.

Lewis (2009)'in çalışması, 1970-2006 dönemleri arasında Birleşmiş̧ Milletler İstatistik Birimi’nden alınan inşaat sektörü çıktısı, gayrisafi yurtiçi hasıla ve inşaat sektörü gayrisafi sabit sermaye oluşumu verileriyle, 7 gelişmiş ve 18 gelişmekte olan ülkeyi ${ }^{4}$ kapsamaktadır. Değişkenlerin birbirleriyle olan ilişkilerini betimsel olarak ele alan çalışma ekonomi kalkındıkça inşaat

${ }^{4}$ Gelişmiş ülkeler: İngiltere, Japonya, Fransa, Almanya, Kanada, Amerika, Norveç Gelişmekte olan ülkeler: Afganistan, Hindistan, Kenya, Pakistan, Sri Lanka, Filipinler, Nijerya, Tayland, Kolombiya, Ekvator, Paraguay, Meksika, Yunanistan, Guyana, Jamaika, Trinidad ve Tobago, Türkiye, Çek Cumhuriyeti 
sektörünün ekonomi içindeki öneminin azaldığına işaret etmektedir. İktisadi kalkınmanın erken aşamalarında inşaat sektörü ekonomik faaliyetlerin önemli bir kısmını kapsamakta ve ekonominin modernizasyonunda önemli bir rol üstlenmektedir.

Bir diğer kapsayıcı betimsel çalışma, inşaat sektörünün yatırımları ve ekonomik büyüme üzerine Lopes (2009) tarafından yapılmıştır. 1970-2006 dönemini kapsayan bu çalışmada inşaat yatırımları için temsili değişken (proxy) olarak inşaat sektörünün katma değeri alınmıştır. Ekonomik faaliyetin temel göstergesi olarak da gayrisafi yurtiçi hasıla yer almaktadır. Analizde gayrisafi yurtiçi hasıla, inşaat sektörünün gayrisafi sabit sermaye oluşumu ve katma değeri olmak üzere üç temel gösterge kullanılmıştır. Birleşmiş Milletler Ulusal Hesaplar İstatistikleri ve Dünya Bankası veri setlerinin kullanıldığ1 çalışma 93 ülkeyi kapsamaktadır. Bu ülkeler, düşük, orta ve yüksek gelirli ülkeler olmak üzere üç alt gruba ayrılmış, dünyanın farklı ülkelerindeki genel görünümü yansıtabilmek amacıyla da bu üç grup, Dünya Bankası'nın bölgesel sınıflandırmasına dayanarak 8 alt gruba ayrıştırılmıştır. Araştırma, iktisadi gelişmenin ilk aşamalarında inşaat sektörünün gayrisafi çıktı içindeki payının, kişi başına gelir artışı ile birlikte artış eğilimi gösterdiğini ortaya koymaktadır. İktisadi gelişmenin belirli bir aşamasında inşaat sektörünün büyüme hızı gayrisafi yurtiçi hasılanın büyüme hızının altına düşmektedir. Buradan ülkeler sürdürülebilir bir ekonomik büyüme patikasına girdiklerinde, inşaat sektöründeki büyümenin milli gelirdeki büyümeyi yakalayabildiği sonucu çıarilabilir.

Ruddock ve Lopes (2006)'in 75 ülke için Birleşmiş Milletler veri setinden aldıkları inşaat sektörünün gayrisafi katma değeri ile kişi başına düşen gayrisafi yurtiçi hasılayı kullanarak ülkelerin inşaat faaliyetlerinin düzeyi ile ekonomik gelişme aşamaları arasındaki ilişkiyi araştırdıkları çalışmaları ekonomide inşaat sektörünün payı ile ilgili ters U şeklindeki yapının geçerli olduğunu ortaya koymaktadır. Bir başka deyişle, inşaat sektörünün ekonominin toplam çıktısı içindeki payı, ekonominin gelişme sürecinde ilk önce artmakta daha sonra azalmaktadir.

İnşaat sektörünün iktisadi büyümeye olan katkısını ekonometrik yöntemler kullanarak analiz eden çalışmalardan biri de Osei (2013)'nin Gana için yaptığ1 araştırmadır. 1993-2011 dönemlerini kapsayan çalışmada bir taraftan inşaat sektör endeksi ilk defa Gana için hesaplanmış, ardından sektörün ekonomik büyümeye olan katkısını ve sektörün faaliyetleri ile ekonomik büyüme arasındaki ilişkinin yönünü tespit etmek amaciyla Engel Granger nedensellik testi ve Johansen eş bütünleşme analizi uygulanmıştır. Çalışma, inşaat sektörünün Gana ekonomisi için son 20 yllda önemini giderek arttırdığına dikkat çekmekte, sektörün faaliyetlerinin ekonomik büyümeye olumlu katkıda bulunduğunu, bu anlamda inşaat sektörünün faaliyetleri ile ekonomik büyüme arasında pozitif bir ilişkinin olduğunu ortaya koymaktadır. 
Bu konuda bir başka ülke örneği, Sri Lanka için yapılan çalışmadır. 1990-2009 dönemlerini kapsayan çalş̧ma, inşaat sektöründeki faaliyetlerle ekonomik büyüme arasındaki ilişkiyi Granger nedensellik testini kullanarak tespit eder. Çalışmanın bulguları, söz konusu dönem için ulusal ekonomik faaliyetlerin inşaat sektörünü sürüklediğini, ekonomiden inşaat sektörüne doğru bir nedenselliğin geçerli olduğunu fakat bunun tersi durumun tespit edilemediğini göstermektedir (Ramachandra, vd. 2013: 60-61).

İnşaat sektörü ile ilgili GÇ analizleri, genel olarak, sektörün ileriye doğru bağlantı göstergelerinin geriye doğru bağlantılarından daha düşük olduğuna işaret etmektedir (Bon ve Pietroforte, 1990: 240; Giang ve Pheng, 2011: 121122). Fakat gelişmiş ülkelere bakıldığında, geriye doğru bağlantılar, ileriye doğru bağlantılardan göreli olarak düşük kalmaktadır (Pietroforte ve Gregori, 2003: 323-325). Gelişmekte olan ülkelerde inşaat sektörü için yapilan GÇ analizlerinin önemli bir kısm1, sektörün geriye doğru bağlantı göstergelerinin ileriye doğru bağlantı göstergelerinden çok daha önemli ve etkili olduğunu bulgulamaktadır. (Bon, vd. 1999:544; Wu ve Zhang, 2005: 907-910; Kofoworola ve Gheewala, 2008: 1234-1236).

İnşaat sektörünü geri ve ileri bağlantılarının nispi önemleri üzerinden değerlendiren çalışmaların yanında, Bielsa ve Duerte (2011)'nin inşaat sektörünün anahtar sektör olma halini sorgulayan ve sektörün ekonomi üzerinde bozucu etkilerinin de olabileceğini ortaya koyan çalışmaları, sektörün eleştirel bir gözle ele alınması açısından önem arz etmektedir. 1996-2006 tarihleri arasinda OECD ülkelerinde meydana gelen çarpıcı büyümede İspanya'nın payına dikkat çeken çalışma, ülkenin büyümesinde tetikleyici rolü inşaat sektörünün üstlendiğini ortaya koymaktadır. İnşaat sektörünün ekonomiye olan bağımlılığını tespit etmeyi ve sektörün aşırı büyümesinin ekonomi üzerindeki bozucu etkisini tahmin etmeyi amaçlayan çalışma, 11 OECD ülkesi ${ }^{5}$ ve Amerika için OECD'den alınan 2000 yllı GÇ tablolarını ve İspanya için İspanya Ulusal İstatistik Enstitüsü (INE) tarafindan yayınlanan 2004 yılı GÇ tablosunu kullanmıştır. İnşaat ve gayrimenkul sektörleri inşaat bloku olarak adlandırılmakta ve bu bloğun diğer sektörlerle olan ilişkisi, geriye ve ileriye doğru bağlantı katsayıları yardımıyla analiz edilmektedir. Çalışmanın bulguları, gayrimenkul sektörü ile birlikte değerlendirildiğinde inşaat bloğunun geriye doğru bağlantılarının oldukça güçlü olması nedeniyle doğrudan ve dolaylı olarak, diğer sektörlere kıyasla daha fazla sayıda iş yaratabildiğini fakat verimliliğin düşük kaldığını göstermektedir. Sektörün ileriye doğru bağlantılarının düşük olmasının yanı sıra, çalışma, inşaat sektörünün kendi nihai talebine yüksek düzeyde bağımllık gösteren bir sektör olduğunu bulgulamıştır. $\mathrm{Bu}$ durum inşaat talebindeki düşüşün ekonomi üzerinde kırılgan bir etki yaratabileceğini göstermektedir. Çalışma bu yönüyle, inşaat

${ }^{5}$ Adı geçen 11 ülke şunlardır: Belçika, Danimarka, Finlandiya, Fransa, Almanya, İtalya, Hollanda, Norveç, İspanya, İsveç ve İngiltere. 
sektöründeki aşırı büyümenin ekonomi üzerindeki bozucu etkisine dikkat çekmektedir.

Türkiye'de inşaat sektörünün ekonomik büyüme ile olan ilişkisini araştıran çalışmalarda, genel olarak, inşaat sektörünün faaliyetleri ile ekonomik büyüme arasındaki nedensellik test edilmiştir. Özkan, vd. (2012) tarafindan, 1987-2008 dönemleri arasında aylık verilerle, altyapı yatırımları ile kamu ve özel olmak üzere bina ve konut yatırımları olarak alınan inşaat verisi ve gayrisafi yurtiçi hasıla artış oranı arasındaki kısa ve uzun dönemli nedensellik ilişkileri, EngelGranger eş-bütünleşme ve Granger nedensellik testleri kullanılarak analiz edilmiştir. Çalışmanın bulguları, altyapı yatırımları ile bina ve konut yatırımları arasında uzun dönemli bir ilişkinin varlığını ortaya koymaktadır. Fakat söz konusu ilişki bina ve konut yatırımları ile gayrisafi yurtiçi hasılar arasında gözlemlenememiştir. Ayrıca altyapı yatırımlarındaki uzun dönemli ilişkinin kısa dönemli ekonomik şoklardan etkilenmediği, buna karşın bina ve konut yatırımlarının kısa dönemli şoklardan etkilendiği bulunmuştur. Genel olarak, gayrisafi yurtiçi hasıladan inşaat yatırımlarına doğru bir nedensellik ilişkisi söz konusu olmakta, kamu yatırımlarında ise bu ilişkinin çift yönlü bir şekilde olduğu bulgulanmaktadır.

Türkiye ekonomisinde sektörel GÇ analizlerinin yapıllıyor olmasına karşın inşaat sektörü özelinde yapılan çalışmalar sınırlı kalmaktadır. İnşaat sektörüne ilişkin olarak yapılan GÇ analizlerinin bulguları dikkate alındı̆̆ında sektörün geriye doğru bağlantılarının oldukça güçlü fakat ileriye doğru bağlantılarının ise zayıf kaldığı görülmektedir. (Bon vd., 1999; İlhan ve Yaman, 2010; Gündeş, 2011). Türkiye'de inşaat sektörü için yapılan GÇ analizleri arasında öne çıkan bir çalışma da, yapısal yol çözümlemesini' ${ }^{6}$ kullanması ile de bu konuda ilk olan Şenesen vd. (2013)'nin çalışmalarıdır. 2002 TÜIK GÇ tablosunu 31 sektörle toplulaştırarak kullanan çalışma, inşaat sektörünün nihai talep karşısında istihdam ve ithalatı uyarma yapılarını incelemiştir. Inşaat sektörünün geriye doğru istihdamı uyarma katsayısının 31 sektör içerisinde 10 . sırada olduğu ve nihai talep karşısında uyarılan istihdamın daha çok inşaat sektörü içinde kaldığ1, ayrıca inşaat sektörünün nihai talebindeki artışın sektörlerin ithalatlarını geriye doğru sınırlı ölçüde uyardığı, çalışmanın sonuçları arasındadır.

Gül (2017)'ün WIOD kullanarak Türkiye'nin inşaat sektörünü GÇ analizi ile incelediği çalışması, bu konudaki en güncel çalışmalardan birini oluşturmaktadır. Ulusal Hesaplar Sistemi'nin (SNA-System of National Accounts) 1993 versiyonuna bağlı kalınarak oluşturulmuş ve uluslararası standart sanayi sınıflaması revizyon 3'e göre sınıflandırılmış 35 sektörü ve 40 ülkeyi 1995-2011 dönemi ile kapsayan veri seti kullanılarak yapılan çalışmada,

\footnotetext{
${ }^{6}$ Yapısal Yol Çözümlemesi, GÇ analizinde herhangi bir sektörde ortaya çıkan nihai talep artışının hangi sektörlerde istihdam ya da geliri uyardığını ortaya çıkarmayı amaçlayan, bir başka deyişle, çarpan etkisini sektörel olarak ayrıştıran bir yaklaşımdır.
}

138 
2002-2011 dönemi için inşaat sektörünün geri ve ileri bağlantılar1 ile girdi, çıktı, istihdam ve gelir çarpanları hesaplanmıştır. Ortaya konulan sonuçlar, geri bağlantıların ileri bağlantılara göre güçlü olduğu, inşaat sektörünün istihdam yaratma kapasitesinin diğer sektörlere kiyasla yüksek fakat gelir yaratma kapasitesinin düşük olduğunu göstermektedir.

Türkiye'de inşaat sektörünün GÇ modellemesi ile analiz edildiği bu yeni çalışma, SNA 2008 versiyonuna bağlı kalınarak güncelleştirilmiş, uluslararası standart sanayi sınıflaması revizyon 4'e göre sınıflandırılmış 56 sektörü ve 43 ülkeyi 2000-2014 dönemi ile kapsayan tamamen yeni bir veri setini kullanmaktadır. Ayrıca çalışma, hem inşaat sektörünün ithal girdi kullanımına dikkat çekerek, hem de literatürü güncelleştirmek suretiyle önceki çalışmadan farklılaşmakta ve Gül (2017)'yi bir adım öteye taşımaktadır.

\section{Veri ve Yöntem}

Bu çalışmada, Ulusal Hesaplar Sistemi (SNA-2008) ve Avrupa Hesaplar Sistemi (ESA-2010) öncülüğ̈unde, Avrupa Birliği ülkelerinde yapılan kapsamlı milli gelir revizyonları sonucu oluşturulan GÇ tabloları dikkate alınmış, bu çerçevede, World Input-Output Database (WIOD) projesinden alınan güncellenmiş 2000-2014 yılları arası GÇ tabloları kullanılmıştır. WIOD, Avrupa Birliği 7. Çerçeve Programı kapsamında desteklenen ve küreselleşmenin ülkelerarası ticaret yapıları, çevresel sorunlar ve sosyoekonomik gelişmeler üzerindeki etkilerini analiz etmek amacıyla, 2000'den 2014'e kadar 28'i Avrupa Birliği üyesi, 15’i de diğer olmak üzere toplam 43 ülkeyi kapsayan bir çalışmadır . Analize konu olan GÇ tabloları 56 sektörden oluşmaktadır. Tablolar, benzer özellik gösteren sektörler bir araya getirilmek suretiyle 18 sektör altında toplulaştırılmıştır. Sektörlerin uyum tablosu ekte verilmiştir.

2000'den 2014 yılına kadar toplulaştırılmış 18 sektörden oluşan 15 GÇ tablosu için geriye ve ileriye doğru bağlantılar, basit girdi ve çıktı çarpanları, kesikli (truncated) çıktı, istihdam ve gelir çarpanları ile kesikli tip II istihdam ve gelir çarpanları hesaplanmıştır. Kesikli çarpanlar, girdi katsayıları ya da teknik katsayılar matrisinin hanehalkı ile kapatılması sonucu oluşturulmuş matrisler kullanılarak hesaplanmaktadır. Esasen hanehalkı ile kapatılmış katsay1 matrislerinden hesaplanan çarpanlar toplam çarpanlar olarak adlandırılmaktadır. Bu toplam çarpanların, hanehalkını dişarıda bırakarak orijinal n sektör için hesaplanan kısmı kesikli çarpanlar olarak tanımlanmaktadır. Kesikli çarpanlar, hanehalkını üretici bir sektör gibi sektörel işlemler matrisine dahil etmektedir. Bu durumda herhangi bir sektörün nihai talebinde meydana gelen artışın o sektörün üretimini uyarma

${ }^{7}$ Ayrıntılı bilgi için bkz. Timmer, M. P. (2012). 
etkisi, içine hanehalkının gelir ve harcama etkisinin katılmasından ötürü, basit çarpanlara göre daha gerçekçi olarak hesaplanabilmektedir.

Geri ve ileriye doğru bağlantı katsayıları aşağıdaki (2) ve (3) numaralı denklemlerde gösterildiği şekilde hesaplanmaktadır ${ }^{8}$.

$$
\begin{gathered}
G B_{i n S ̧}^{S}=\frac{G B_{i n s}}{(1 / n) \sum_{i=1}^{n} a_{i j} \sum_{j=1}^{n} a_{i j}} \\
\dot{\mathrm{I}} B_{i n S ̧}^{S}=\frac{\dot{\mathrm{I}} B_{i n \varsigma}}{(1 / n) \sum_{i=1}^{n} b_{i j} \sum_{j=1}^{n} b_{i j}}
\end{gathered}
$$

üzerinde $S$ ifadesi olan katsayılar standardize edilmiş geriye ve ileriye doğru bağlantı katsayılarını göstermektedir. Geriye doğru bağlantı katsayıları, sektörlerin kullandıkları girdilerin toplam arza (GÇ matrisinin sütun toplamına) bölünmesi ile elde edilen girdi katsayılarını kullanır. İleriye doğru bağlantı katsayıları ise sektörlerin kullandıkları girdilerin toplam kullanıma (GÇ matrisinin satır toplamına) bölünmesi ile elde edilen çıktı katsayılarını kullanmaktadır. Standardize edilmiş geriye doğru bağlantılar, girdi katsayılarının sütun toplamı olarak ifade edilen geriye doğru bağlantıların, girdi katsayılarının satır ve sütun toplamlarının çarpımının sektör sayısına bölünmüş değerine oranlanması ile elde edilmektedir. Standardize edilmiş ileriye doğru bağlantılar ise yine aynı yöntemle hesaplanmakta, bu defa hesaplamaya konu olan katsayılar çıktı katsayıları olmaktadır9.

8 Literatürde geri ve ileri bağlantıların hesaplanmasında temelde iki yöntemin izlendiği görülmektedir. Bunlardan ilki, Chenery ve Watanabe (1958)'nin girdi katsayıları matrisinin sütun ve satır toplamlarını sırasıyla geri ve ileri bağlantı olarak ele aldığı yaklaşımlarıdır. Diğeri ise, Rasmussen (1957)'nin ilk olarak ortaya koyduğu daha sonra da Hirschman (1958) tarafindan geliştirilen Leontief ters matrisinin sütun ve satır toplamlarının geri ve ileri bağlantı olarak ölçüldüğü yöntemdir. Rasmussen, geri bağlantı etkisini bir endüstrinin "dağılım gücü-power of dispersion", ileri bağlantı etkisini ise "dağılım duyarlılı̆̆1-sensitivity of dispersion" olarak tanımlamıştır. Literatürde genel olarak, Chenery ve Watanabe'nin bağlantı yaklaşımları doğrudan bağlantılar, Rasmussen-Hirschman'in yaklaşımları ise toplam bağlantılar olarak ele alınmaktadır. İleri bağlantıların hesaplanmasında girdi katsayıları matrisi ya da Leontief ters matrisinin satır toplamlarının esas alınması, tüm sektörlerde aynı anda üretim ya da nihai talep artışının gerçekleşmesi gerektiği varsayımına dayandığından, gerçekçi bulunmamış ve ileri doğru bağlantıları hesaplamada, literatürde arz yönlü model olarak adlandırılan Ghosh modeli kullanılmıştır. Ghosh modeli çıktı katsayıları matrisini esas almakta ve ileri bağlantılar, çıktı katsayıları matrisinin ya da Ghosh ters matrisinin satır toplamları alınarak hesaplanmaktadır (Lahr ve Dietzenbacher, 2001:2; Miller ve Lahr, 2001: 408-411; Drejer, 2002: 2-12). Bu çalışmada geri bağlantıları hesaplamada Chenery ve Watanabe'nin yaklaşımı esas alınmış, ileri bağlantıları hesaplamada ise Ghosh modeline sadık kalınmıştır.

${ }^{9}$ Girdi katsayıları matrisi A; bu matrisin elemanları $a_{i j}$, çıktı katsayıları matrisi B ve bu matrisin elemanları da $b_{i j}$ ile gösterilmektedir. 
Tablo 1: Çarpanlar

\begin{tabular}{|c|c|c|}
\hline Çarpanlar & Talep yönlü & Arz yönlü \\
\hline Basit & 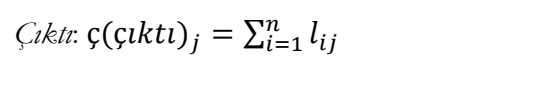 & $\begin{array}{l}\text { Girdi: } c(\text { girdi })_{i}= \\
\sum_{j=1}^{n} g_{i j}\end{array}$ \\
\hline \multirow[t]{3}{*}{ Kesikli } & i) $C \imath$ lktı: $\overline{c ̧}[\operatorname{çlkt\imath }(k)]_{j}=\sum_{i=1}^{n} \bar{l}_{\square j}$ & \\
\hline & ii) İstibdam/Gelir: $\overline{c ̧}[h(k)]_{j}=\sum_{i=1}^{n} a_{n+1, i} \bar{l}_{i j}$ & \\
\hline & 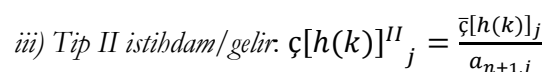 & \\
\hline
\end{tabular}

Kaynak: Miller ve Blair (2009)

Tablo 1 çalışmada kullanılan çarpanların nasıl hesaplandığını göstermektedir. $c ̧(c ̧ l k t \imath)_{j}$, j sektörü için n sektörlü orijinal GÇ modelinden elde edilen çıktı çarpanını simgelemektedir. Bu çarpan ayrıca basit çarpan olarak da bilinir. $\bar{c}[c ̧ \iota t ı t(k)]_{j}$, hanehalkının bir üretici sektör olarak sektörler arası işlemler matrisine dahil edilmesiyle, bir başka deyişle GÇ modelinin hanehalk1 ile kapatılmasıyla oluşturulmuş ve daha sonra hanehalkı dışarıda bırakılarak hesaplanmış olan kesikli çıktı çarpanını göstermektedir. Sektörel istihdam ve gelir çarpanları, sektörde çalışan hanehalkı için hesaplandığından çarpan ifadesi içinde hanehalkını temsilen $b$ harfi yer almaktadır. Bu çerçevede, $\bar{c}[h(k)]_{j}$ ve ç $[h(k)]^{I I}{ }_{j}$ sırasıyla kesikli istihdam/gelir çarpanı ile kesikli tip II istihdam/gelir çarpanını temsil etmektedir. Girdi çarpanı da arz yönlü çarpanları temsilen ç $(\text { girdi })_{i}$ şeklinde ifade edilmektedir.

Basit girdi ve çıtı çarpanlanı, sırasıyla Leontief ve Ghosh ters matrisleri kullanılarak hesaplanmaktadır. (4) ve (5) numaralı denklemlerde yer alan $x$, sektörün üretimini temsil eden üretim vektörüdür. $j$ sektörünün çıtı çarpanı, Leontief ters matrisinde $j$ sektörünün sütun elemanlarının toplamıdır ve $\mathbf{j}$ sektörünün çıktısı için 1 parasal birimlik nihai talebi karşılayabilmek amacıyla hem $j$ sektöründe hem de ekonominin diğer sektörlerinde yaratılması gereken üretimin parasal değerini vermektedir .

$$
x=L . f
$$

(4) numaralı denklem çıktı çarpanının genel formunu vermektedir. Denklemde $L$ Leontief ters matrisini ifade etmekte ve $(I-A)^{-1}$ ile temsil edilmektedir. $f$ ise nihai talep vektörüdür. Aynı şekilde girdi çarpanları da (5) numaralı denklemdeki gibidir.

$$
x=G . v
$$


Bu denklemde de $G$, Ghosh ters matrisini temsil etmekte ve $(I-B)^{-1}$ 'e eşit olmaktadır. $v$ ise katma değerdir. $j$ sektörü için girdi çarpanı, Ghosh ters matrisinde $j$ sektörünün satır toplamıdır ve $j$ sektörünün birincil girdiler olarak adlandırılan katma değer unsurlarında meydana gelen 1 parasal birimlik artışın, $j$ sektörü de dahil olmak üzere ekonominin tüm sektörlerinde üretilen toplam çıktı üzerindeki etkisini ölçmektedir.

Toplam çıtı çarpanları, $n$ tane sektör olduğu düşünüldügünde $(n+1)$ 'nci sektör olarak hanehalkının üretim yapan bir sektör gibi sektörler arası işlemler matrisine dahil edilmesiyle elde edilen Leontief ters matrisinin ilgili sektörünün sütun elemanlarının toplamı ile elde edilmektedir.

Kesikli çıktı çarpanları ise $(n+1)$ sektörlü Leontief ters matrisinde, hanehalkı dışarıda tutularak ilgili sektörün $n$ sektöre kadar olan sütun elemanlarının toplamı şeklinde ifade edilmektedir. Kesikli istihdam ve gelir çarpanları, sırasıyla, sektörlerin istihdam ve gelir katsayılarından ${ }^{10}$ oluşan istihdam ve gelir vektörlerinin (n+1) sektörlü hesaplanan Leontief ters matrisinin $n$ sektöre kadar olan kısmı ile çarpımı sonucunda elde edilmektedir. Bu sayede sektörün nihai talebindeki 1 parasal birimlik artışın, tüm diğer sektörlerce ne kadarlık doğrudan, dolaylı ve uyarılmıs fiziki istihdam veya parasal gelir yaratacağ hesaplanmış olmaktadır. Tip II istihdam ve gelir çarpanlar1 ${ }^{11}$ ise, sırasıyla, sektördeki 1 parasal birimlik talep artışı karşısında, tüm ekonomide yaratılan doğrudan, dolaylı ve uyarılmış fiziki istihdam veya gelir artışlarını, sektörün kendi üretimi için gerekli istihdam veya gelir artışları ile karşlaştırarak vermektedir. Dolayısıyla tip II çarpanı ne kadar yüksekse, talep şoku verilen sektörün ekonomi çapında yaygın etkisi o kadar artmaktadır.

\section{Ampirik Bulguların Analizi}

GÇ analizleri bir ekonominin sektörleri arasındaki bağlantıları, sektörlerin birbirleri ile olan girdi ve çıkt kullanımları üzerinden açıklamakta, dışsal talep ya da arz değişmelerinin sektörel üretim üzerindeki etkilerini hesaplayarak, herhangi bir sektörün ekonomide sürükleyici bir rol üstlenip üstlenemediği konusunda öngörülerde bulunmaktadır. İnşaat sektörü, güçlü geriye ve ileriye doğru bağlantıları nedeniyle ekonominin sürükleyici gücünü oluşturan sektörlerin başında gelmektedir. Genel olarak inşaat sektörü, geriye ve ileriye doğru bağlantıları çerçevesinde ele alındığında, 20 sektör içinde ilk 4'de yer almaktadır (Balaban, 2011: 19; Giang ve Pheng, 2011: 119-120). Talep yönünden bakıldığında inşaat faaliyetleri diğer sektörlerden yüklü miktarlarda ara girdi kullanarak ekonomik büyümeyi uyarmakta, arz yönünde ise mal ve hizmet üretimi için gerekli olan altyapıyı sağlamaktadır. İnşaat sektörü,

\footnotetext{
10 İstihdam katsayısı, sektörel istihdamın sektörün çıktısına olan oranıdır. Gelir katsayısı ise GÇ matrisinde sektörün çalışanlarına yapılan ödemenin sektörün çıktısına olan oranıdır.

11 Burada tip I, $n$ sektörlü, tip II de hanehalkı ile kapatılmış $(n+1)$ sektörlü Leontief ters matrisinden elde edilen hesapları göstermektedir.
} 
işgücünü yoğun olarak kullanan bir sektör olduğundan dolayı, istihdama katkı sağlamada önemli bir işlev görmektedir.

Çalışmanın bu kısmında geriye ve ileriye doğru bağlantılar ve çarpanlar yardımıyla inşaat sektörünün ekonomi içindeki konumu ortaya konulmakta ve sektörün ekonomiyi sürükleyen lokomotif bir sektör olup olmadığı, GÇ analizinden elde edilen bulgular ışığında test edilmektedir.

Sektörlerin geriye ve ileriye doğru bağlantı katsayılarının 1'e göre aldıkları konum, sektörlerin birbirleriyle olan girdi-çıktı ilişkisinin yapısını belirlemektedir. Şöyle ki, bir sektörün hem ileriye hem de geriye doğru bağlantı katsayısı 1'den küçükse, o sektör bağımsız olarak tanımlanmakta, bu da sektörün diğer sektörlerle ileri ve geri bağlantılarının güçlü olmadığ1 anlamına gelmektedir. Hem ileriye hem de geriye doğru bağlantı katsayısının 1'den büyük olduğu durumda, sektör bağıml olarak tanımlanmakta ve diğer sektörlerle ileri ve geri bağlantılarının güçlü olduğu sonucu ortaya çıkmaktadır. Geriye doğru bağlantı katsayısının 1'den büyük, ileriye doğru bağlant1 katsayısının ise 1'den küçük olduğu durumda, sektörün üretimi diğer sektörlerin çıktılarına bağımlı hale gelmiştir. Bu durumda sektör, sektörler arası arza bağımlı sektör olarak tanımlanmaktadır. Son olarak, geriye doğru bağlantı katsayısının 1'den küçük, ileriye doğru bağlantı katsayısının ise 1'den büyük olduğu durumda, sektörün girdi kullanımı, kendi ürettiği çıktının girdi olarak kullanılmasına göre zayıf kalmakta, bu durumda sektör, sektörler arası talebe bağıml sektör olarak tanımlanmaktadır (Miller ve Blair, 2009: 559-560).

Tablo 2, yukarıdaki açıklamalar 1şığında sektörlerin ${ }^{12}$ ileriye ve geriye doğru bağlantı katsayıları çerçevesinde bağımlılık ilişkilerini özetlemektedir.

\footnotetext{
12 Rakamların karşılık geldiği sektörler şu şekilde sıralanmıştır: 1: Tarım, avcllık, ormancılık, balıkçılı; 2: Madencilik ve taşocakçllı̆̆1; 3: İmalat; 4: Enerji arzı ve dağılımı; 5: Kimyasallar ve kimyasal ürünler; 6: kauçuk ve plastik ürünler: 7: Diğer metalik olmayan mineral ürünler; 8: Ana metaller ve fabrikasyon metal ürünleri; 9: Her türlü makine; 10: İnşaat; 11: Ticaret; 12: Kara taşımacılı̆̆1; 13: Diğer taşımacılık; 14: Finansal aracılık hizmetleri; 15: Emlak faaliyetleri; 16: Makine ekipman kiralama ve diğer is faaliyetleri; 17: Kamu yönetimi ve savunma hizmetleri, zorunlu sosyal güvenlik hizmetleri; 18: Diğer hizmetler.
} 
Tablo 2. Sektörlerarası Bağımlılık

8(2008, 2011, 2013, 2014), 9(2013, 2014), 10(2013), 11(2000-2010), Genel olarak bağımsız $\quad$ 12(2000-2007 ve 2010), 15, 17, 18

\begin{tabular}{|c|c|}
\hline Sektörler arası arza bağımlı & $\begin{array}{l}\mathbf{3}, \mathbf{5}(2011-2014), \mathbf{6}(2013, \quad 2014), \\
\mathbf{8}(2009-2010 \text { ve } 2012), \mathbf{9}(2000-2012), \\
\mathbf{1 0}(2000-2012 \text { ve } 2014)\end{array}$ \\
\hline Sektörler arası talebe bağımlı & $\begin{array}{l}\text { 1, 2, 12(2008, } 2009 \text { ve } 2011-2014), \\
14,16\end{array}$ \\
\hline Genel olarak bağımlı & $\begin{array}{l}\mathbf{4}, \mathbf{5}(2000-2010), \mathbf{6}(2000-2012), \mathbf{7}, \\
\mathbf{8}(2000-2007), \mathbf{1 1}(2013,2014), \mathbf{1 3}\end{array}$ \\
\hline
\end{tabular}

Tablo 2'ye göre ileri ve geri bağlantıları zayıf olan ve bu yüzden bağımsız olarak adlandırılan sektörler, ticaret, kara taşımacılığı, emlak faaliyetleri, kamu yönetimi, savunma ve zorunlu sosyal güvenlik ile diğer hizmetler şeklinde hizmet niteliği öne çıkan sektörlerdir. Geri bağlantıları kuvvetli sektörler, imalat, her türlü makine ve inşaat gibi fazla girdi kullanan sektörler olmaktadır. ileri bağlantıları kuvvetli sektörler ise tarım, madencilik, finans ve makine ekipman kiralama gibi üretim sürecinde girdiyi sınırlı kullanan fakat kendi çıktısının çok sayıda sektörün üretiminde girdi olarak kullanıldığı sektörlerdir. İleri ve geri bağlantıları kuvvetli sektörler ise enerji, kimya sanayi, kauçuk ve plastik sanayi, diğer metalik olmayan mineral ürünleri ve diğer taşımacılık şeklindedir.

İncelenen 15 yıllık dönem ortalamaları dikkate alındığında, inşaat sektörü, geriye doğru bağlantı katsayıları ve basit çıtı çarpanları sıralamasında 18 sektör arasında 9. sırada; ileriye doğru bağlantı katsayıları ve girdi çarpanları sıralamasında ise 17. sırada yer almaktadır. Bunun dışında kesikli çıktı çarpanları arasında 12. sırada, kesikli gelir çarpanları arasında 10. sırada kesikli tip II gelir çarpanları arasında 11. sırada, kesikli istihdam çarpanları arasında 6. sırada ve kesikli tip II istihdam çarpanları arasında ise 16 . sırada bulunmaktadir. 
Tablo 3. İnşaat sektörünün bağlantı katsayıları ve çarpanları*

\begin{tabular}{|c|c|c|c|c|c|c|c|c|c|c|c|c|c|c|c|}
\hline & 2000 & 2001 & 2002 & 2003 & 2004 & 2005 & 2006 & 2007 & 2008 & 2009 & 2010 & 2011 & 2012 & 2013 & 2014 \\
\hline GDB & 1,114 & 1,104 & 1,093 & 1,090 & 1,087 & 1,074 & 1,058 & 1,048 & 1,036 & 1,055 & 1,057 & 1,023 & 1,039 & 0,977 & 1,018 \\
\hline IDB & 0,136 & 0,189 & 0,165 & 0,157 & 0,125 & 0,114 & 0,110 & 0,121 & 0,135 & 0,157 & 0,143 & 0,129 & 0,143 & 0,144 & 0,150 \\
\hline ÇkÇ & 1,947 & 1,847 & 1,804 & 1,791 & 1,748 & 1,738 & 1,685 & 1,686 & 1,646 & 1,728 & 1,698 & 1,605 & 1,669 & 1,599 & 1,642 \\
\hline GrÇ & 1,106 & 1,133 & 1,117 & 1,111 & 1,085 & 1,077 & 1,072 & 1,079 & 1,083 & 1,097 & 1,089 & 1,076 & 1,086 & 1,084 & 1,087 \\
\hline KÇßৎ̧ & 2,400 & 2,290 & 2,204 & 2,174 & 2,114 & 2,096 & 2,028 & 2,031 & 1,981 & 2,090 & 2,036 & 1,891 & 2,000 & 1,910 & 1,967 \\
\hline KGÇ & 0,283 & 0,276 & 0,256 & 0,252 & 0,245 & 0,241 & 0,234 & 0,236 & 0,232 & 0,246 & 0,238 & 0,215 & 0,238 & 0,227 & 0,235 \\
\hline KtipIIGÇ & 2,559 & 2,504 & 2,322 & 2,280 & 2,221 & 2,188 & 2,124 & 2,136 & 2,104 & 2,232 & 2,158 & 1,944 & 2,153 & 2,053 & 2,126 \\
\hline Klusç & $0,000 \mathrm{si}$ & 1,0000101 & $0,000 \times 87$ & $0,000<s$ & 0,00050 & 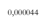 & 0,0000039 & 0,0000032 & 8,, $000 \times 29$ & 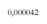 & 0.,00036 & 0,000004 & 0,00037 & agonosis & 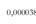 \\
\hline KtipIIIstç & 1,948 & 2,006 & 2,068 & 2,004 & 2,047 & 1,944 & 1,908 & 1,919 & 1,864 & 1,749 & 1,753 & 1,610 & 1,713 & 1,650 & 1,678 \\
\hline
\end{tabular}

*: GDB: Geriye doğru bağlantı; İDB: İleriye doğru bağlantı; ÇkÇ: Çıktı çarpanı; GrÇ: Girdi çarpanı; KÇkÇ: Kesikli çıktı çarpanı; KGÇ: kesikli gelir çarpanı; KtipIIGÇ: Kesikli tip II gelir çarpanı; KİstÇ: Kesikli istihdam çarpanı; KtipIIİstÇ: Kesikli tip II istihdam çarpanı.

Tablo 3'de İnşaat sektörünün bağlantı katsayıları ve çarpanları yer almaktadır. Grafik 4 ise tablo 3'de yer alan bağlantı ve çarpanların zaman içindeki değişim seyrini vermektedir.

\section{Grafik 4. İnşaat sektöründe bağlantı ve çarpanların zaman içindeki değişimi}

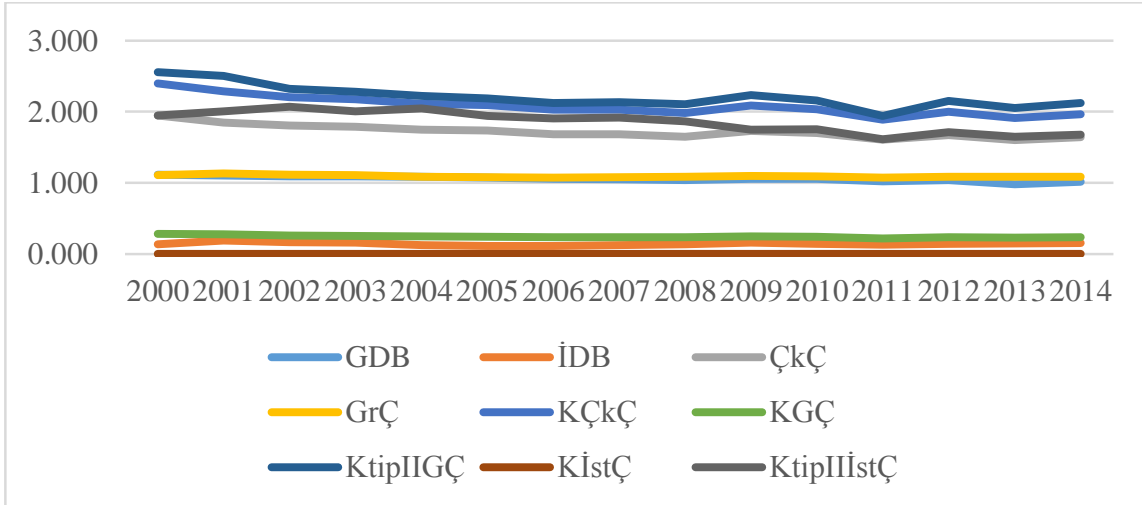

Geriye ve ileriye doğru bağlantı katsayıları açısından bakıldığında inşaat sektörünün geriye doğru bağlantılarının kuvvetli, ileriye doğru bağlantılarının ise zayıf olduğu görülmektedir. Sektörel sıralamada istihdam çarpanının tüm sektörler içinde 6. sırada olmasına rağmen, kesikli tip II istihdam çarpanının 16. sırada yer alması, inşaat sektörünün, talep artış karşısında tüm ekonomi çapında istihdam yaratabildiğini fakat bu istihdam artı̧ının yalnızca inşaat sektörü ile sınırlı kaldığını göstermektedir. kesikli gelir çarpanı ile kesikli tip II 
gelir çarpanının sıralamadaki konumları sırasıyla 10 ve 11'dir. Kesikli gelir çarpanı ile kesikli tip II gelir çarpanının sıralamadaki yerlerinin birbirine çok yakın olması, sektörün nihai talep artışı karşısında, tüm ekonominin gelir yaratma etkisi ile bu etkinin yaygınlığının aynı olduğunu ortaya koymaktadır. Buradan dolaylı olarak inşaat sektörünün gelir yaratma etkisinin istihdam yaratma etkisine göre daha güçlü olduğu yorumu yapılabilir.

Grafik 4'deki çarpanlar ve bağlantı katsayılarının hareketlerine bakıldığında, özellikle kesikli tip II gelir çarpanı, kesikli çıktı çarpanı, kesikli tip II istihdam çarpanı ve basit çıktı çarpanının 2002-2008 dönemlerinde istikrarlı bir biçimde azalış eğilimi gösterdikleri, 2008'den sonra 2009'a kadar kesikli tip II gelir çarpanı ile kesikli çıktı çarpanının bir miktar düzelme göstererek yukarrya doğru çıktığı görülmektedir. Her iki çarpanda da 2009'dan sonra 2011'e kadar bir azalma gözlenmekte, 2011 sonrasında ise artış göze çarpmaktadır. 2009 krizi sonrası inşaat sektörü hızlı bir toparlanma kaydetmiş, 2010 ve 2011 yıllarında sırasıyla \%17,1 ve \%24,7 oranlarında büyümüştür. Bu hızlı toparlanmanın çarpanlar üzerindeki olumlu etkisini 2011 yllından sonraki artış için yorumlayabilmek mümkündür.

\section{Grafik 5: İnşaat sektörünün çıktı çarpanına en yüksek katkı sağlayan ilk 5 sektörün inşaat sektörünün nihai talebi ile bağlantılı çarpan katsayıları ve bu katsayıların zaman içindeki değişimleri}

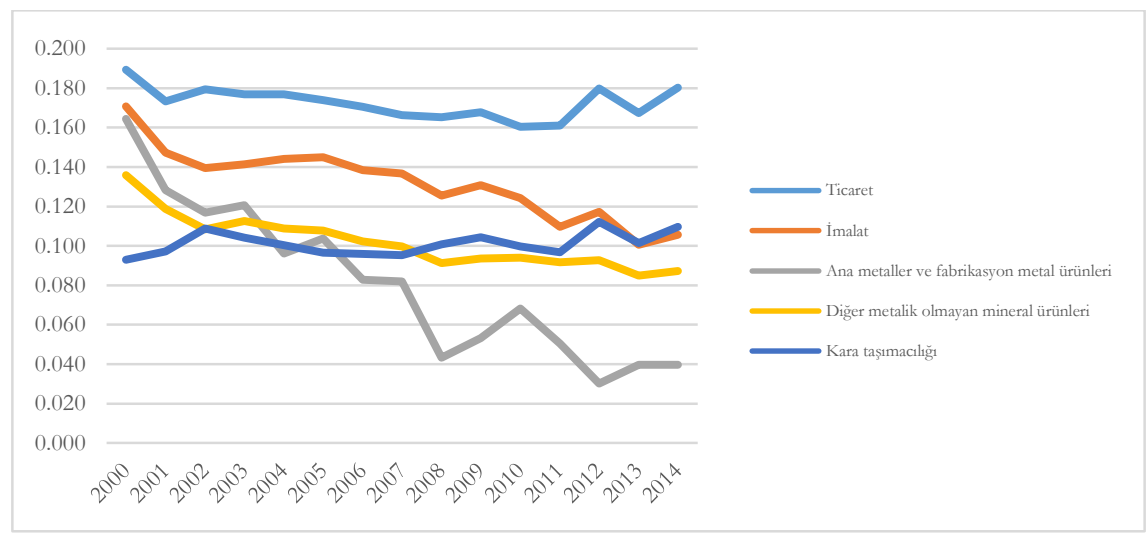

Grafik 5, inşaat sektörünün nihai talebindeki artış karşısında üretimi en fazla uyaran ilk 5 sektörün, 2000-2014 dönemleri arasındaki hareketini göstermektedir. Grafikte yer alan çarpan göstergeleri, hanehalk1 ile genişletilmiş Leontief ters matrisinde inşaat sektörü sütununun ilgili sektörlere karşılık gelen katsayıları olarak alınmıştır. Bu çarpan katsayıları, inşaat sektörünün nihai talebindeki 1 parasal birimlik artışı karşılayabilmek için ilgili sektörlerin ne kadar üretim yapması gerektĭgini ortaya koymaktadırlar. Grafikte ilk olarak, 15 ylllık dönem boyunca ticaret sektörünün artış eğilimi gösterdiği, bunun karşısında ana metal ve fabrikasyon metal ürünleri sektörünün keskin bir azalma eğilimi içerisinde olduğu tespit edilmektedir. 146 
İnşaat sektörünün nihai talebindeki genişleme, ticaret sektöründeki üretimi giderek artan bir şekilde uyarmakta ve bu iki sektör arasındaki güçlü geri bağlantı ilişkisi, sektörün toplam çıktı çarpanında baskın bir rol oynamaktadır ${ }^{13}$.

Diğer çarpıcı gözlem, inşaat sektörünün en fazla girdi talep ettiği sektörler arasında ilk üçte yer alan ana metal ve fabrikasyon metal ürünleri sektörünün, inşaat sektörünün nihai talebini karşılamada çarpan etkisinin giderek azalma eğiliminde olmasıdır.

\section{Grafik 6: İnşaat sektörünün kullandığ1 toplam ana metaller ve fabrikasyon metal ürünler girdisinin yerli ve ithal kullanım paylarının zaman içindeki değişimi}

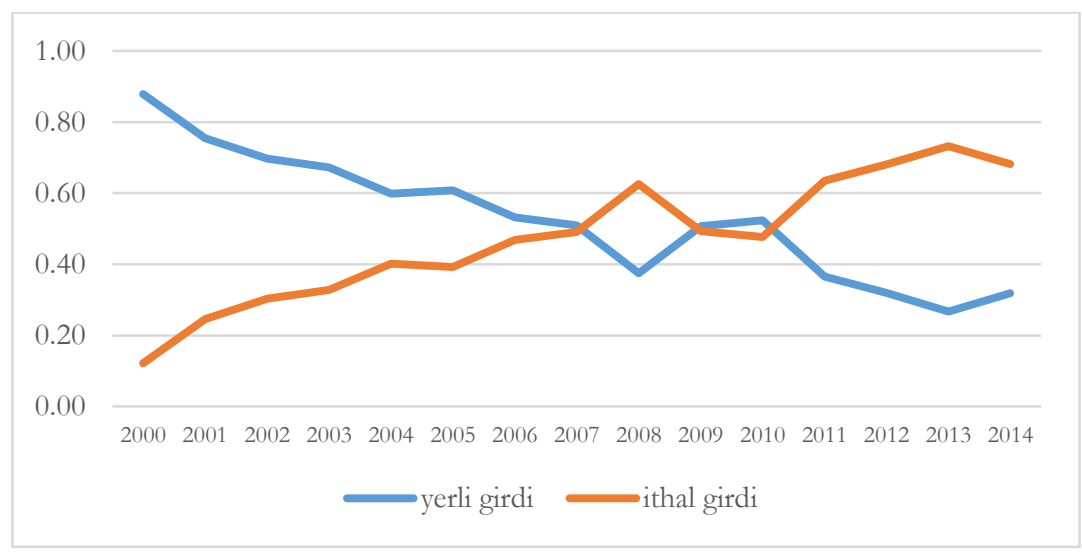

Kaynak: WIOD

Grafik 6, bu duruma bir açıklık getirmektedir. Esasen sektörlerin çarpan etkilerinin hesaplanmasında sektörlerin yalnızca yurtiçi girdi kullanımları esas alınmış, ithal girdi kullanımı dışarıda bırakılmıştır. İnşaat sektörünün ana metal ve fabrikasyon metal ürünleri kullanımında yerli girdi payı giderek azalırken, buna koşut olarak, ithal girdi payı giderek artmaktadır. İthal girdi adeta yerli girdi ile ikame edilmektedir. Çarpan etkilerinin hesaplanmasında bu durum, inşaat sektörünün nihai talebindeki artışı karşılamada ana metal ve fabrikasyon metal ürünleri sektörünün üretimini uyarma etkisinin olduğundan düşük olarak hesaplandığı anlamına gelmektedir.

\footnotetext{
${ }^{13}$ Çalışmada ticaret sektörünü oluşturan sektörler: 1) Toptan ve perakende ticaret ile motorlu kara taşıtlarının ve motosikletlerin onarım ve hizmetleri; 2) Toptan ticaret, motorlu kara taşıtları ve motosikletler hariç; 3) Perakende ticaret, motorlu kara taşıtları ve motosikletler hariç; 4) Konaklama ve yiyecek hizmetleri.
} 


\section{Sonuç ve Öneriler}

İnşaat sektörünün 2000'den 2014'e kadar uzanan 15 yıllık performansını GÇ analizi üzerinden ele alan bu çalışma, bir taraftan sektöre iliş̧kin temel makroekonomik göstergeler ile ampirik gözlemlerde bulunmakta, diğer taraftan da sektörün yapısal özellikleri ve diğer sektörlerle olan girdi-çıtı ilişkilerini geriye ve ileriye doğru bağlantı katsayıları ve çarpanlar üzerinden analiz etmektedir. Çalışmanın amacı, teşvik politikaları ve yasal düzenlemeler ile devlet tarafindan desteklenen inşaat sektörünün ekonominin sürükleyici sektörlerinden biri olup olmadığını ampirik gözlemler ve GÇ analizi üzerinden sorgulamaktır.

Makroekonomik göstergeler üzerine yapılan gözlemler, 2000-2014 dönemlerinde inşaat sektörünün gayrisafi yurt içi hasılaya göre ortalama olarak daha yüksek bir büyüme performansı sergilediğini, gayrisafi yurtiçi hasıla içerisindeki paylar dikkate alındığında ise sektörün tek başına 20 sektör arasında altıncı sırada yer aldığını, gayrimenkul faaliyetleri ile birlikte ele alındığında ise $\% 15^{\prime}$ lik dönem payı ortalaması ile imalat sektöründen sonra ikinci sıraya yerleştiğini ortaya koymaktadır. Gayrisafi sabit sermaye oluşumunun kompozisyonunda inşaatın payı 2009'da yüzde 51,7'den 2014'de yüzde 57,3'e çımış, buna karşın makine ve teçhizatın payı yüzde 39,1'den yüzde 34,9'a gerilemiştir. Ayrıca, birikimli deneyim fonksiyonu, incelenen dönemde gayrisafi yurtiçi hasıladaki büyümenin inşaat sektörünün büyümesine katkıda bulunduğuna işaret etmektedir.

GÇ analizinin ortaya koyduğu sonuçlar, genel olarak inşaat sektörünün geriye doğru bağlantı katsayıları ve basit çıtı çarpanları sıralamasında 18 sektör arasında 9. sırada; ileriye doğru bağlantı katsayıları ve girdi çarpanları sıralamasında ise 17. sırada yer aldığını, dolayısıyla sektörün geriye doğru bağlantılarının kuvvetli, ileriye doğru bağlantılarının ise zayıf olduğunu göstermektedir. Ayrıca istihdam ve gelir çarpanları birlikte değerlendirildiğinde, inşaat sektörünün talep artışı karşısında istihdam yaratabilme kapasitesinin kendisi ile sinırlı kaldığı, gelir yaratma etkisinin, istihdama göre daha yaygın olduğu sonucu ortaya çıkmaktadır. Çarpanların zaman içindeki hareketlerine baktığımızda, inşaat sektörünün talebindeki artışı karşılamada sırasılyla gelir yaratma ve üretim kapasitesinde artışı simgeleyen kesikli tip II gelir çarpanı ile kesikli çıtı çarpanının 2011'den sonra birbirine koşut olarak arttı̆̆ gözlemlenmektedir. İş̧aat sektörünün toplam çıktı çarpanına en çok katkı sağlayan, bir başka deyişle, inşaat sektörünün talebinin üretimini en çok tetiklediği ilk 5 sektörün inşaat sektörü ile ilgili çarpan katsayılarının zaman içindeki gelişimi dikkate alındığında, ticaret sektörünün giderek önemini arttırdığı, ana metaller ve fabrikasyon metal ürünler sektörünün çarpan etkisinin giderek zayıfladığ1 görülmektedir. Ana metaller ve fabrikasyon metal ürünler sektörü inşaat sektörünün en fazla girdi kullandığı sektörlerin başında gelmektedir. Sektörlerin çarpan etkilerinin 
hesaplanmasında yalnızca yurtiçi girdi kullanımlarının esas alınması ve bu sektörde ithal girdinin yerli girdi ile ikame edilerek kullanıliyor olması nedeniyle, Ana metaller ve fabrikasyon metal ürünler sektörünün, inşaat sektörünün nihai talebini karşılamada ortaya koyduğu çarpan etkisi giderek zayıflamaktadır.

Çalışmanın mevcut bulguları inşaat sektörünün ekonomiyi sürükleme etkisinin sınırlı olduğunu ortaya koymaktadır. Bu yüzden kaynakların ileriye ve geriye doğru bağlantıları güçlü, ihracatta katma değeri yüksek ve uluslararası pazarlarda rekabet edebilir ürünler ortaya çıkaran sektörlere tahsis edilmesi, istikrarlı büyümenin yolunu açacaktır. 


\section{Kaynakça}

Balaban, O. (2011) İnşaat Sektörü Neyin Lokomotifi?, Birikim, 270: 19-26.

Bielsa, J. ve Duarte, R. (2011) Size and Linkages of the Spanish Construction Industry: Key Sector or Deformation of the Economy, Cambridge Journal of Economics, 35, 317-334.

Bon, R. (1992) The Future of International Construction: Secular Patterns of Growth and Decline, Habitat International, 16(3), 119-128.

Bon, R. ve Pietroforte, R. (1990) Historical Comparison of Construction Sector in the US, Japan, Italy and Finland Using Input-Output Tables, Construction Management and Economics, 8(3), 233-247.

Bon, R.; Birgönül, T. ve Özdoğan, İ. (1999) An Input-Output Analysis of the Turkish Construction Sector, 1973-1990: A Note, Construction Management and Economics, 17(5), 543-551.

Chenery, H. B. ve Watanabe, T. (1958) International Comparisons of the Structure of Production, Econometrica, 26(4), 487-521.

Dietzenbacher, E. ve Lahr, M. L. (2001) Introduction, M. L. Lahr ve E. Dietzenbacher (der.), Input-Output Analysis: Frontiers and Extensions, New York: Palgrave.

Drejer, I. (2002) Input-Output Based Measures of Interindustry Linkages Revisited-A Survey and Discussion, IIOA 14th International Conference on Input-Output Techniques, Canada.

Giang, D. T. H. ve Pheng, L. S. (2011) Role of Construction in Economic Development: Review of Key Concepts in the Past 40 Years, Habitat International, 35, 118-125.

Gül, Z. B. (2017) Construction Industry in Turkey: An Input-Output Analysis Using the World Input-Output Database (WIOD) for the 20022011 Periods, Atatürk Üniversitesi İktisadi ve İdari Bilimler Fakültesi Dergisi, 31(1), 157-174.

Gündeş, S. (2011) Exploring the Dynamics of the Turkish Construction Industry Using Input-Output Analysis, Construction Management and Economics, 29(1), 59-68.

Hirschman, A. O. (1958) The Strategy of Economic Development, New Haven, Yale University Press.

İhan, B. ve Yaman, H. (2010) A Comparative Input-Output Analysis of the Construction Sector in Turkey and EU Countries, Engineering, Construction and Arcbitectural Management, 18(3), 248-265. 
Kofoworola, O. F. ve Gheewala, S. (2008) An Input-Output Analysis of Thailand's Construction Sector, Construction Management and Economics, 26(11), 1227-1240.

Lewis, T. M. (2009) Quantifying the GDP-Construction Relationship, L. Ruddock (der.), Economics for the Modern Built Environment, New York: Taylor and Francis. 34-59.

Lopes, J. (2009) Investment in Construction and Economic Growth: A Long Term Perspective, L. Ruddock (der.), Economics for the Modern Built Environment, New York: Taylor and Francis. 94-112

Miller, R. E. ve Blair, D. P. (2009) Input-Output Analysis: Foundations and Extensions, Second Edition, New York: Cambridge University Press.

Miller, R. E. ve Lahr, M. L. (2001) A Taxonomy of Extractions, R. E. Miller ve M. L. Lahr (der.), Regional Science Perspectives in Economic Analysis, UK: Emerald Group Publishing Limited. 407-441.

Osei, V. (2013) The Construction Industry and Its Linkages to the Ghanaian Economy-Policies to Improve the Sector's Performance, International Journal of Development and Economic Sustainability, 1(1), 5672.

Özkan, F., Özkan, Ö. ve Gündüz, M. (2012) Causal Relationship between Construction Investment Policy and Economic Growth in Turkey, Technological Forecasting \& Social Change, 79, 362-370.

Pietroforte, R. ve Gregori, T. (2003) An Input-Output Analysis of the Construction Sector in Highly Developed Economies, Construction Management and Economics, 21(3), 319-327.

Ramachandra, T.; Rotimi, J. O. B. ve Rameezdeen, R. (2013) Direction of the Causal Relationship between Construction and the National Economy of Sri Lanka, Journal of Construction in Developing Countries, 18(2), 49-63.

Rasmussen, P. N. (1957) Studies in Inter-Sectoral Relations, North-Holland: Amsterdam.

Ruddock, L. ve Lopes, J. (2006) The Construction Sector and Economic Development: the 'Bon Curve', Construction Management and Economics, 24(7), 717-723.

Strassmann, P. (1970) The Construction Sector in Economic Development, Scottish Journal of Political Economy, 17(3), 391-409.

Şenesen, G. G.; Kaya, T. ve Şenesen, Ü. (2013) İnşaat Kesimi İstihdam mı Yaratıyor, Dışalımı mı Uyarıyor?, Ekonomi-tek, 2(3), 23-46. 
Tan, W. (2002) Construction and Economic Development in Selected LDCs: Past, Present and Future, Construction Management and Economics, 20(7), 593-599.

Timmer, M. P. (2012) The World Input-Output Database (WIOD): Contents, Sources and Methods, WIOD Working Paper, 10, 1-73.

Turin, D. A. (1969) Industrialization of Developing Countries: Problems and ProspectsConstruction Industry, UNIDO monograph No.2: New York.

Wu, X. and Zhang, Z. (2005) Input-Output Analysis of the Chinese Construction Sector, Construction Management and Economics, 23(9), 905-912.

www.tuik.gov.tr

www.wiod.org

www.stats.oecd.org 


\section{Ek. Sektörlerin Uyum Tablosu}

\begin{tabular}{|c|c|c|c|c|}
\hline 1 & $\begin{array}{c}\text { Tarım ve avcilık ürünleri, ve ilgili } \\
\text { hizmetler }\end{array}$ & $1+2+3$ & 1 & Tarım, avcıllk, ormancillk ve balıkçılık \\
\hline 2 & Orman ürünleri ve ilgili hizmetler & & & \\
\hline 3 & $\begin{array}{l}\text { Balık ve balıkçllk ürünleri; su } \\
\text { ürünleri; balkçıllk için destekleyici } \\
\text { hizmetler }\end{array}$ & & & \\
\hline 4 & Madencilik ve taşocakçllı̆ 1 & 4 & 2 & Madencilik ve taşocakçıllğ1 \\
\hline 5 & Gıda, içecekler ve tütün ürünleri & $5+6+7+8+9+22$ & 3 & İmalat \\
\hline 6 & $\begin{array}{c}\text { Tekstil, giyim eşyası, deri ve ilgili } \\
\text { ürünler }\end{array}$ & & & \\
\hline 7 & $\begin{array}{l}\text { Kereste, ağaç ürünleri ve mantar } \\
\text { ürünleti (mobilya hariç); hasır ve } \\
\text { örme malzemesinden ürünler }\end{array}$ & & & \\
\hline 8 & Kağıt ve kağt ürünleri & & & \\
\hline 9 & Basım ve kayit hizmetleri & & & \\
\hline 10 & Kok ve rafine petrol ürünleri & $10+24+25$ & 4 & Enerji arzı ve dağılımı \\
\hline 11 & Kimyasallar ve kimyasal ürünler & $11+12$ & 5 & Kimyasallar ve kimyasal ürünler \\
\hline 12 & $\begin{array}{l}\text { Temel eczacillk ürünleri ve } \\
\text { müstahzarları }\end{array}$ & & & \\
\hline 13 & Kauçuk ve plastik ürünleri & 13 & 6 & Kauçuk ve plastik ürünleri \\
\hline 14 & $\begin{array}{l}\text { Diğer metalik olmayan mineral } \\
\text { ürünleri }\end{array}$ & 14 & 7 & $\begin{array}{l}\text { Diğer metalik olmayan mineral } \\
\text { ürünleri }\end{array}$ \\
\hline 15 & Ana metaller & $15+16$ & 8 & $\begin{array}{l}\text { Ana metaller ve fabrikasyon metal } \\
\text { ürünleri }\end{array}$ \\
\hline 16 & $\begin{array}{l}\text { Fabrikasyon metal ürünler, } \\
\text { makine ve ekipmanlar hariç. }\end{array}$ & & & \\
\hline 17 & $\begin{array}{c}\text { Bilgisayarlar ile elektronik ve optik } \\
\text { urrünler }\end{array}$ & $17+18+19+20+21+23$ & 9 & Her türlü makina \\
\hline 18 & Elektrikli techizat & & & \\
\hline 19 & $\begin{array}{l}\text { Başka yerde sınıflandırılmamış } \\
\text { makine ve ekipmanlar. }\end{array}$ & & & \\
\hline 20 & $\begin{array}{c}\text { Motorlu kara taşıtları, treyler } \\
\text { (römork) ve yarı treyler (yarı } \\
\text { römork) }\end{array}$ & & & \\
\hline 21 & Diğer ulaşım araçları & & & \\
\hline 22 & Mobilya ve diğer mamul eşyalar & & & \\
\hline 23 & $\begin{array}{l}\text { Makine ve ekipmanların onarımı } \\
\text { ve kullanımı }\end{array}$ & & & \\
\hline 24 & $\begin{array}{l}\text { Elektrik, gaz, buhar ve } \\
\text { iklimlendirme }\end{array}$ & & & \\
\hline
\end{tabular}


İnşaat Sektörünün Dinamikleri: Türkiye için 2000-2014 Girdi-Çıktı ...

\begin{tabular}{|c|c|c|c|c|}
\hline 25 & $\begin{array}{l}\text { Doğal su; suyun arttlması ve } \\
\text { temini hizmetleri }\end{array}$ & & & \\
\hline 26 & Kanalizasyon hizmetleri & & & \\
\hline 27 & İnşaat ve inşaat işleri & 27 & 10 & İnşaat \\
\hline 28 & $\begin{array}{l}\text { Toptan ve perakende ticaret ile } \\
\text { motorlu kara tasstlarnnin ve } \\
\text { motosikleteterin onarm hizmetleri }\end{array}$ & $28+29+30+36$ & 11 & Ticaret \\
\hline 29 & $\begin{array}{l}\text { Toptan ticaret, motorlu kara } \\
\text { taştları ve motosikletler hariç }\end{array}$ & & & \\
\hline 30 & $\begin{array}{l}\text { Perakende ticaret, motorlu kara } \\
\text { taşıtları ve motosikleterter hariç̣ }\end{array}$ & & & \\
\hline 31 & $\begin{array}{l}\text { Kara taşımacilly̆ı ve boru hatt } \\
\text { taşımaclly̆g hizmetleri }\end{array}$ & 31 & 12 & Kara taşımacilı̆ı̆ \\
\hline 32 & Su yolu taşımacilı̆ı hizmetleri & $32+33+34$ & 13 & Diğer taşımacilkk \\
\hline 33 & Hava yolu taşımacilığ hizmetleri & & & \\
\hline 34 & $\begin{array}{l}\text { Depolama ve taşımacillk için } \\
\text { destek hizmetleri }\end{array}$ & & & \\
\hline 35 & Posta ve kurye hizmetleri & & & \\
\hline 36 & Konaklama ve yiyecek hizmetleri & & & \\
\hline 37 & Yayincllk hizmetleri & & & \\
\hline 38 & $\begin{array}{l}\text { Sinema filmi, video ve televizyon } \\
\text { programı yapimcllk hizmetleri; } \\
\text { ses kaydi ve müzik yaymlama; } \\
\text { programcllk ve yayncillk } \\
\text { hizmetleri }\end{array}$ & & & \\
\hline 39 & Telekomünikasyon hizmetleri & & & \\
\hline 40 & $\begin{array}{l}\text { Bilgisayar programlama, } \\
\text { danışmanlik ve ilgili hizmetler; } \\
\text { bilgi hizmetleri }\end{array}$ & & & \\
\hline 41 & $\begin{array}{l}\text { Finansal hizmetler (sigorta ve } \\
\text { bireysel emeklilik hariç) }\end{array}$ & $41+42+43$ & 14 & Finansal araclik hizmetleri \\
\hline 42 & $\begin{array}{l}\text { Sigorta, reasürans ve emeklilik } \\
\text { fonlart hizmeteri, zorunlu sosyal } \\
\text { güvenlik hariç }\end{array}$ & & & \\
\hline 43 & $\begin{array}{l}\text { Finansal hizmetler ile sigorta } \\
\text { hizmetlerine yardimct hizmetler }\end{array}$ & & & \\
\hline 44 & Gayrimenkul hizmetleri & 44 & 15 & Emlak faaliyetleri \\
\hline 45 & $\begin{array}{l}\text { Hukuk ve muhasebe hizmetleri; } \\
\text { idare merkezi hizmetleri; idari } \\
\text { dantşsmanllk hizmeteri }\end{array}$ & & & \\
\hline 46 & $\begin{array}{l}\text { Mimarllk ve mühendislik } \\
\text { hizmetleri; teknik test ve analiz } \\
\text { hizmetleri }\end{array}$ & & & \\
\hline 47 & $\begin{array}{l}\text { Bilimsel arassturma ve geliş̧trme } \\
\text { hizmetleri }\end{array}$ & & & \\
\hline
\end{tabular}


Zafer Bartş GÜL, Misra ÇAKALOĞLU

\begin{tabular}{|c|c|c|c|c|}
\hline 48 & $\begin{array}{l}\text { Reklamclik ve pazar araşurması } \\
\text { hizmetleri }\end{array}$ & & & \\
\hline 49 & $\begin{array}{l}\text { Diğer mesleki, bilimsel ve teknik } \\
\text { hizmetler; veterinerlik hizmetleri }\end{array}$ & & & \\
\hline 50 & $\begin{array}{l}\text { Yönetim ve destek hizmet } \\
\text { faaliyetleri }\end{array}$ & 50 & 16 & $\begin{array}{l}\text { Makine ekipman kiralama ve diğer iş } \\
\text { faaliyetleri }\end{array}$ \\
\hline 51 & $\begin{array}{c}\text { Kamu yönetimi, savunma } \\
\text { hizmatleri; zorunlu sosyal güvenlik }\end{array}$ & 51 & 17 & $\begin{array}{l}\text { Kamu yönetimi, savunma hizmetleri; } \\
\text { zorunlu sosyal güvenlik }\end{array}$ \\
\hline 52 & Eğtim hizmetleri & & & \\
\hline 53 & $\begin{array}{l}\text { İnsan sağhlğı ve sosyal bakım } \\
\text { hizmetleri }\end{array}$ & & & \\
\hline 54 & Diğer hizmet faaliyetleri & & & \\
\hline 55 & $\begin{array}{l}\text { Hanehalkının issveren olarak } \\
\text { faaliyetleri; hanehalkninn kendi } \\
\text { kullanimm isint tassifif edilmemis mal } \\
\text { ve hizmet üretme faaliyetleri }\end{array}$ & & & \\
\hline 56 & $\begin{array}{l}\text { Sinır ötesi organizasyonların } \\
\text { faaliyetleri }\end{array}$ & $\begin{array}{c}26+35+37+38+39+40+45+46+47+48+ \\
49+52+53+54+55+56\end{array}$ & 18 & Diğer Hizmetler \\
\hline
\end{tabular}

